\title{
Lung bioavailability of generic and innovator salbutamol metered dose inhalers
}

\author{
D J Clark, J Gordon-Smith, G McPhate, G Clark, B J Lipworth
}

\begin{abstract}
Background - The aim of this study was to determine whether significant differences exist in lung bioavailability between generic (Salamol, Salbulin) and innovator (Ventolin) formulations of inhaled salbutamol given by metered dose inhalers. Methods - Ten healthy volunteers of mean age 20.5 years with a forced expiratory volume in one second $\left(\mathrm{FEV}_{1}\right)$ of $112 \cdot 1 \%$ predicted were studied in a randomised double blind single dosing crossover study. Salbutamol, $1200 \mu \mathrm{g}$, was given with mouth rinsing and lung bioavailability was assessed by measuring plasma salbutamol levels and urine excretion of salbutamol.

Results - No differences were seen between innovator and generic salbutamol metered dose inhalers in plasma salbutamol levels, urinary salbutamol excretion, or extrapulmonary $\beta_{2}$ activity. The maximum plasma salbutamol concentration (mean Cmax) and time to maximum concentration (median Tmax) were: Ventolin ( $2.93 \mathrm{ng} / \mathrm{ml}, 10$ minutes), Salbulin (3.01 $\mathrm{ng} /$ $\mathrm{ml}, 10$ minutes), Salamol ( $3.33 \mathrm{ng} / \mathrm{ml}, 10$ minutes). The geometric mean ratio and 95\% confidence interval for $\mathrm{Cmax}$ were: Salbulin/Ventolin $1.02(0.69$ to 1.41$)$ and Salamol/Ventolin $1.13(0.94$ to 1.35$)$.

Conclusions - No differences are apparent between the two generic and innovator formulations of salbutamol metered dose inhaler in terms of lung bioavailability.

(Thorax 1996;51:325-326)
\end{abstract}

Keywords: generic salbutamol, lung bioavailability, metered dose inhalers.

Considerable debate continues on the issue of generic and innovator salbutamol metered dose inhalers. ${ }^{12}$ In contrast to the normal procedure for oral medications, the Medicines Control Agency only required in vitro testing for inhaled forms of generic salbutamol before licensing. We report on an in vivo study of the lung bioavailability of generic and innovator salbutamol metered dose inhalers. A pharmacokinetic evaluation of lung bioavailability was performed using measurement of plasma salbutamol concentration. ${ }^{34}$ Comparison was made between the measurement of lung bioavailability using plasma and a method using 30 minute urinary excretion of salbutamol..$^{5}$ In addition, the pharmacodynamic effects in terms of extrapulmonary $\beta_{2}$ activity were also evaluated.

\section{Methods}

Ten healthy men of mean (SE) age $20.5(0.3)$ years and a forced expiratory volume in one second $\left(\mathrm{FEV}_{1}\right)$ of $112 \cdot 1(2 \cdot 8) \%$ predicted were studied in a randomised double blind crossover study. Single doses of $1200 \mu \mathrm{g}$ salbutamol as Ventolin metered dose inhaler (Allen \& Hanburys, Uxbridge, Middlesex, UK), Salbulin metered dose inhaler (3M, Loughborough, Leics, UK) and Salamol metered dose inhaler (Baker Norton, Harlow, Essex, UK) were given as 12 sequential $100 \mu \mathrm{g}$ puffs over six minutes. Mouth rinsing was performed after each puff to obviate gastrointestinal absorption.

The subjects were studied on three days each separated by one week. They were instructed to inhale slowly from residual volume with breath holding for 10 seconds, and the technique was checked with an airways inhalation monitor (Vitalograph Ltd, Buckingham, UK) at each visit. Heart rate, tremor and potassium were measured at baseline and after 20 minutes. Plasma salbutamol levels were measured at 5, 10 and 20 minutes after inhalation of the last puff. Urine was collected for measurement of salbutamol excretion in the first 30 minutes after inhalation.

Finger tremor was measured with an accelerometer transducer (Entron, Ealing, UK), ${ }^{6}$ heart rate was measured from standard lead II of an electrocardiogram monitor, and plasma potassium levels were assayed by flame photometry using an IL943 analyser (Instrumentation Laboratory Ltd, Warrington, UK). The intra-assay and interassay values for analytical imprecision were $0.41 \%$ and $1.04 \%$, respectively.

Plasma and urinary salbutamol levels were assayed by high performance liquid chromatography (HPLC) with solid phase extraction and fluorescence detection as previously described. ${ }^{7}$ The analytical imprecision for plasma salbutamol was $3.9 \%$ (intra-assay) and $4 \cdot 1 \%$ (interassay) at $4 \mathrm{ng} / \mathrm{ml}$, and $11 \cdot 8 \%$ (intra-assay) and $12.6 \%$ (interassay) at $2 \mathrm{ng} / \mathrm{ml}$; and for urinary salbutamol was $3.6 \%$ (intraassay) and $7 \cdot 2 \%$ (interassay). The HPLC detection limit for salbutamol was $1 \mathrm{ng} / \mathrm{ml}$.

DATA ANALYSIS

The results were analysed using the Statgraphics statistical software package (STSC Software Publishing Group, Rockville, Maryland, USA). Comparisons for all parameters were made by multifactorial analysis of variance (MANOVA) and Duncan's multiple range testing using subjects and treatments as within factors for the analysis. A probability value of p $<0.05$ (two tailed) was considered significant.

Results

No significant differences were seen between innovator and generic salbutamol metered dose 
Table 1 Mean (95\% confidence intervals) for Cmax, Cav, and urinary salbutamol and mean (range) Tmax with three formulations of salbutamol

\begin{tabular}{|c|c|c|c|c|}
\hline & $\underset{(n g / m l)}{C \max }$ & $\begin{array}{l}\text { Cav } \\
(n g / m l)\end{array}$ & $\underset{(\min )}{\operatorname{Tmax}}$ & $\begin{array}{l}\text { Urinary salbutamol } \\
(\mu \mathrm{g} / 30 \mathrm{~min})\end{array}$ \\
\hline Ventolin & $\begin{array}{l}2.93 \\
(2.44 \text { to } 3.42)\end{array}$ & $\begin{array}{l}2 \cdot 68 \\
(2 \cdot 30 \text { to } 3 \cdot 07)\end{array}$ & $\begin{array}{l}10 \\
(5-10)\end{array}$ & $\begin{array}{l}45 \cdot 1 \\
(34 \cdot 6 \text { to } 55 \cdot 7)\end{array}$ \\
\hline Salbulin & $\begin{array}{l}3 \cdot 01 \\
(2 \cdot 52 \text { to } 3 \cdot 50)\end{array}$ & $\begin{array}{l}3 \cdot 0 \\
(2 \cdot 59 \text { to } 3 \cdot 42)\end{array}$ & $\begin{array}{l}10 \\
(5-10)\end{array}$ & $\begin{array}{l}56 \cdot 0 \\
(45 \cdot 5 \text { to } 66 \cdot 6)\end{array}$ \\
\hline Salamol & $\begin{array}{l}3.33 \\
(2 \cdot 84 \text { to } 3 \cdot 82)\end{array}$ & $\begin{array}{l}3.09 \\
(2 \cdot 70 \text { to } 3.47)\end{array}$ & $\begin{array}{l}10 \\
(5-10)\end{array}$ & $\begin{array}{l}57 \cdot 0 \\
(46 \cdot 4 \text { to } 67 \cdot 5)\end{array}$ \\
\hline
\end{tabular}

$\mathrm{Cmax}=$ maximal plasma concentration; $\mathrm{Cav}=$ average plasma concentration; Tmax $=$ time to maximal concentration.

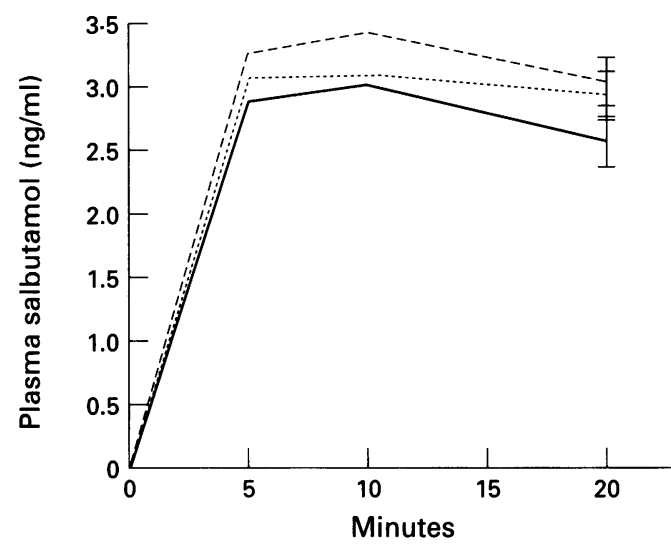

Mean (SE) plasma salbutamol concentrations at 5, 10, and 20 minutes after inhalation of salbutamol as Ventolin (-), Salamol (-.--) Salbulin (.....). No differences in levels were found between the formulations.

inhalers for plasma salbutamol concentration at any individual time point, nor in terms of peak salbutamol concentration (Cmax), average salbutamol concentration (Cav), or time of peak concentration (Tmax) (table 1, figure). The geometric mean ratio $(95 \% \mathrm{CI})$ of Salbulin/Ventolin was $1.02(0.69$ to 1.41$)$ for Cmax and $1.14(0.91$ to 1.44$)$ for Cav. For Salamol/Ventolin the mean ratio was $1 \cdot 13(0.94$ to 1.35$)$ for $\mathrm{Cmax}$ and $1.14(0.97$ to 1.34$)$ for Cav. No significant differences were seen in systemic effects on heart rate, tremor, and plasma potassium levels between innovator and generic metered dose inhalers (table 2).

Urinary salbutamol excretion also showed no significant differences between Ventolin and either Salbulin or Salamol (table 1). The geometric mean ratio for Salbulin/Ventolin was $1.18(0.79$ to 1.73$)$ and for Salamol/Ventolin was $1.26(0.97$ to 1.62$)$. The intersubject coefficient of variation for the three study days was $48 \cdot 1 \%$ for urinary salbutamol, $28 \cdot 0 \%$ for

Table 2 Comparative extrapulmonary $\beta_{2}$ activity of innovator and generic formulations of inhaled salbutamol

\begin{tabular}{llll}
\hline & $\begin{array}{l}\text { Heart rate } \\
\text { (beats } / \mathrm{min})\end{array}$ & $\begin{array}{l}\text { Tremor } \\
\text { (log units) }\end{array}$ & $\begin{array}{l}\text { Fall in potassium } \\
\text { (mmol/l) }\end{array}$ \\
\hline Ventolin & $\begin{array}{l}14.5 \\
(10.0 \text { to } 18.9)\end{array}$ & $\begin{array}{l}0.219 \\
(0.011 \text { to } 0.427)\end{array}$ & $\begin{array}{l}0.31 \\
(0.20 \text { to } 0.42)\end{array}$ \\
Salbulin & $\begin{array}{l}14.2 \\
(9.7 \text { to } 18.7)\end{array}$ & $\begin{array}{l}0.203 \\
(-0.021 \text { to } 0.428)\end{array}$ & $\begin{array}{l}0.49 \\
(0.38 \text { to } 0.62)\end{array}$ \\
Salamol & 16.0 & 0.369 & 0.40 \\
& $(11.5$ to 20.5$)$ & $(0.161$ to 0.577$)$ & $(0.29$ to 0.51$)$ \\
\hline
\end{tabular}

Values are mean change from baseline with $95 \%$ confidence interval. peak plasma salbutamol, and $23 \cdot 3 \%$ for average plasma salbutamol.

\section{Discussion}

We found no significant differences in either plasma or urine pharmacokinetic parameters of lung bioavailability between the innovator and generic formulations. Likewise, all of the calculated dose ratios included unity, again suggesting that there were no differences. We only tested two generic formulations of salbutamol and hence we are unable to deduce any conclusions with respect to substituting other generic metered dose inhalers. Previous in vivo studies have investigated primarily the bronchodilator responses to generic and innovator salbutamol in asthmatic subjects and have not attempted to correlate this with lung bioavailability. $^{8-11}$ The urinary salbutamol excretion method has shown that a generic salbutamol metered dose inhaler can be used in a Volumatic spacer instead of Ventolin. ${ }^{12}$

The plasma concentration time profile seen in our study with a median Tmax of 10 minutes is consistent with rapid absorption across the lung vascular bed and hence Cmax may be used as a direct measure of absolute lung bioavailability. The measurement of urinary 30 minute salbutamol excretion is more indirect and provides a measure of relative bioavailability to the lung. Interestingly, the coefficient of variation for urinary salbutamol was approximately double that for plasma salbutamol. The variability was also evident in the $95 \%$ confidence intervals for the mean ratios which were wider for urinary salbutamol than for plasma salbutamol levels. Thus, the more direct approach of measuring plasma salbutamol would appear to offer greater reliability in the measurement of absolute lung bioavailability for salbutamol.

1 Pearson M, Lewis R, Watson J, Ayres J, Ibbotson G, Ryan D. et al. Generic inhalers for asthma. BMF 1994;309: 1440 .

2 Struke G. Generic inhalers for asthma. Patients titrate dose against response. $B M \mathcal{F}$ 1995;310:602

3 Newnham DM, McDevitt DG, Lipworth BJ. Comparison of the extrapulmonary $\beta_{2}$-adrenoceptor responses and pharmacokinetics of salbutamol given by standard metered-dose inhalers and modified activator device. $B$ $\mathcal{f}$ Clin Pharmacol 1993;36:445-50.

4 Newnham DM, Lipworth BJ. Nebuliser performance, pharmacokinetics, airways and systemic effects of salbutamo given via a noval nebuliser delivery system ("Ventstream") Thorax 1994;49:762-70.

5 Hindle $M$, Chrystyn $H$. Determination of the relative bioavailability of salbutamol to the lung following inhalation. Br 7 Clin Pharmacol 1992;34:311-5.

6 Lipworth BJ, McDevitt DG. Beta-adrenoceptor responses to inhaled salbutamol in normal subjects. Eur $\mathcal{f}$ Clin Pharmacol 1989;36:239-45.

7 Lipworth BJ, Clark RA, Dhillon DP, Moreland TA, Struthers AD, Clark GA et al. Pharmacokinetics, efficacy and adverse effects of sublingual salbutamol in patients with asthma. Eur $\mathcal{F}$ Clin Pharmacol 1989;37:567-71.

8 Ruffin R, Latimer K, Crockett A, Blight M. A comparative bronchodilator study of salbutamol and salbutamol sulphate that were administered by metered dose inhalers. Med f Aust 1989;150:274-7.

9 Saarelainen P, Sovijarvic R. Comparison of acute bronchodilatation effects of two preparations of salbutamol aerosol in asthma. Curr Ther Res 1991;50:224-30.

10 Parki in halation aerosols in release of bronchial obstruction. Curr Ther Res 1983;33:539-42.

11 Vielgren P, Silvasti M, Vielgren M, Paronen P, Tuksinen $H$ Lehti $H$. In vitro behaviour and therapeutic response of Lehti $H$. In vitro behaviour and therapeutic response of salbutamol particles administered from

12 Chege JK, Chrystyn H. Volumatic usage: some generic salbutamol metered dose inhalers can be used. Thorax 1994;49:1162-3. 